\title{
Factors associated with mobility of the oldest old
}

\author{
Fatores associados à mobilidade de idosos longevos
}

\author{
Vanessa Ribeiro dos Santos ${ }^{[a]}$, Diego Giulliano Destro Christofaro ${ }^{[b]}$, Igor Conterato Gomes ${ }^{[c]}$, \\ Ismael Forte Freitas Júnior $^{[\mathrm{b}]}$, Luís Alberto Gobbo ${ }^{[\mathrm{b}]^{*}}$
}

[a] Universidade Estadual Paulista (UNESP), Rio Claro, SP, Brazil

[b] Universidade Estadual Paulista (UNESP), Presidente Prudente, SP, Brazil

[c] Universidade de São Paulo (USP), São Paulo, SP, Brazil

\section{Abstract}

Introduction: Several factors can be associated to the reduction of mobility among the elderly. Early identification of these factors is crucial, since it may lead to prevention of functional dependencies. Objective: To analyze the association between mobility, sociodemographic factors and the prevalence of noncommunicable chronic diseases (NCDs) in oldest old. Methods: The sample consisted of 120 elderly persons aged ( 80 and 95 years), with 76 of them being women ( $83 \pm 3$ years) and 44 of them men ( $83 \pm 3$ years). Sociodemographic factors and NCDs which we studied were: age, gender, marital status, education, nutritional status, ethnicity, hypertension, diabetes and osteoarticular diseases. Mobility was analyzed using a battery of Physical Performance Tests. For statistical analysis we used the chi-square test and binary logistic regression to examine the relationship between sociodemographic factors, NCDs and mobility. SPSS (17.0) software was used for this and the significance level was set at 5\%. Results: Level of education (p $\leq 0.001)$ and age ( $\mathrm{p}=0.034$ ) are the two factors related to low mobility. However, the model built by multiple logistic regression analysis revealed that age is independently related to limited mobility in oldest old people (OR 3.29; 95\% CI 1.09 to 9.87). Conclusion: Thus, oldest old >85 years are at a greater risk of decreased mobility independent of their education, marital and nutritional statuses and gender. We encourage further studies in this area. Studies which will not only address those facts considered in this study but that also examine family-related aspects, especially using longitudinal studies.

Keywords: Mobility Limitation. Demographic Indicators. Chronic Disease. Aged 80 and over.

\footnotetext{
VRS: Doctoral Student, e-mail: van_vrs@yahoo.com.br DGDC: PhD, e-mail: ddcleite@yahoo.com.br

ICG: Doctoral Student, e-mail: igorconterato@yahoo.com.br

IFFJ: PhD, e-mail: ismael@fct.unesp.br

LAG: PhD, e-mail: luisgobbo@fct.unesp.br
} 


\section{Resumo}

Introdução: A redução da mobilidade pode estar relacionada a vários fatores e a identificação precoce desses fatores torna-se fundamental, uma vez que pode auxiliar na prevenção da dependência funcional de idosos. Objetivo: analisar a relação entre mobilidade, fatores sociodemográficos e prevalência de doenças crônicas não transmissíveis (DCNT) em idosos longevos. Métodos: A amostra foi constituída por 120 idosos com idade entre 80 e 95 anos (83 \pm 3 anos), sendo 76 mulheres (83 \pm 3 anos) e 44 homens (83 \pm 3 anos). Os fatores sociodemográficos e DCNT investigados foram: idade, sexo, estado civil, escolaridade, etnia, estado nutricional, hipertensão, diabetes e doenças osteoarticulares. A mobilidade foi analisada por meio da bateria Physical Perfomance Tests. Para tratamento estatístico foram empregados os testes qui-quadrado e regressão logística binária para analisar a associação entre fatores sociodemográficos, DCNT e a mobilidade. O software utilizado foi o SPSS (17.0) e o nível de significância estabelecido foi de 5\%. Resultados: Os fatores relacionados à baixa mobilidade foram a escolaridade $(p \leq 0,001)$ e idade $(p=0,034)$. Contudo, o modelo múltiplo construído pela análise de regressão logística revelou que a idade está independentemente relacionada à limitação da mobilidade em idosos longevos (OR 3,29; IC95\% 1,09-9,87). Conclusão: Dessa forma, idosos longevos com idade >85 anos apresentam mais chance de risco para limitação da mobilidade independente da escolaridade, dos estados civil e nutricional, e do sexo. Incentiva-se a futuros estudos além de abordar os aspectos trabalhados no presente estudo, averiguar também aspectos familiares, e principalmente, em estudos longitudinais.

Palavras-chave: Limitação da Mobilidade. Indicadores Demográficos. Doença Crônica. Idoso de 80 Anos ou mais.

\section{Introduction}

Populational aging is a phenomenon observed throughout the world. It can be seen especially well among individuals who are 80 years old or older, also known as the oldest old. According to the latest census, the Brazilians in this age group accounted for $1.5 \%$ of the total population (1).

As this segment of the population increases, concern about processes inherent to aging, such as physical and morphological changes and especially their influence on mobility, also grows (2 - 5). Mobility refers to movement in all its forms, including basic ambulation, moving from a bed to a chair, walking for leisure and everyday activities, such as climbing a flight of stairs and sweeping the sidewalk, among many others. Mobility also includes work-related activities and physical exercise, for instance driving a car and using various forms of public transportation (5).

It is fundamental that the mobility of older people be assessed based on their performance of physical abilities tests, since most individuals need high walking speed and muscle function (strength and power), as well as good balance to maintain mobility (6). This assessment procedure is widely used and recommended in the field of aging (6).
Besides these physical aspects, there are several other factors which can be related to decreased mobility $(2,3,7-11)$. Early detection of these factors is important to prevent falls, fractures, functional dependency and, consequently, to maintain health and quality of life for the elderly (5). However, published studies do not clearly show if variables, such as economic status, education level and some risk factors for noncommunicable chronic diseases (NCDs), could impair mobility just as much as physical factors do in those who are eighty years old or older.

Thus, the purpose of this study was to analyze the relationship between mobility, socio-demographic factors and prevalence of NCDs in the oldest old people.

\section{Methods}

This study deals with a cross-sectional study that was conducted between October 2009 and May 2010 in the city of Presidente Prudente (Population 210,000 , approximately). Presidente Prudente is located west of São Paulo-Brazil and has a HDI of 0.806 (1). 
We invited 135 elderly people who were 80 years old or older, of both genders who were residents of the municipality to participate in the study. The municipal health department provided us with the names, addresses and telephone numbers of individuals who used the city's public health service. These were invited by way of a phone call. The research being done was also publicized in the local media. Any participants who were unable to walk, bedridden, residents of rural areas, institutionalized, or had a pacemaker were disqualified, as well as those who had incomplete information in the database. Thus, the sample consisted of 120 individuals.

The objectives of the study and the methods to be used for data collection were explained to the participants and they were told that they could stop participating at any time. Only those who signed the "Informed Consent Form" were part of the sample. All protocols were reviewed and approved by the Research Ethics Committee of São Paulo State University (Case no. 26/2009).

Sociodemographic Factors and Noncommunicable Chronic Diseases

The sociodemographic factors and NCDs investigated were: age, gender, marital status, education level, NCDs and ethnicity, all of which were selfreported by the elderly, and nutritional status obtained through the Body Mass Index (BMI) [weight $(\mathrm{kg}) /$ height $(\mathrm{m})^{2}$ ]. Subjects were classified as underweight, normal weight or obese, using the classification suggested by Troiano et al. (12).

To identify the prevalence of NCDs, a morbidity questionnaire was used. This questionnaire is a summary of the Standard Health Questionnaire for Washington State (13), and consists of closed questions that address the presence/absence of chronic diseases, which are divided into three groups: metabolic, cardiovascular and osteoarticular. The main diseases investigated are hypertension, diabetes, dyslipidemia, thyroid disorders, osteoporosis, arthritis/ osteoarthritis and degeneration of the spine.

This questionnaire was adapted for the Brazilian population by Freitas Junior et al. (14). Its use was adopted at present due to the lack of consensus about a widely used and validated, self-reporting protocol to identify the presence of chronic diseases.

\section{Mobility}

Adapted Physical Performance Tests (6) determined mobility according to the individual's performance in tests for: a) static equilibrium; b) usual walking speed; and, c) lower limb strength.

The static balance test has four stages, performed in sequence (10 seconds each): i) standing up with feet together, one next to the other; ii) placing the instep of one foot so that it touches the big toe of the other foot; iii) balancing on one foot, first with one foot and then the other; iv) standing, with one foot in front of the other.

Each stage was considered to be successfully finished when the individual could hold the position described for 10 seconds. Possible scores for this test are as follows: $0=$ disability, unable to hold any of the positions for the stipulated time; 1 = bad, held one position for the stipulated time; 2 = average, successfully held two positions; 3 = good, successfully held three or four positions. The scores of the four stages were added together to compute the final score.

A 3 meter walking test was used to evaluate each individual's walking speed. The elderly were instructed to walk naturally, as if they were walking at home. The shortest time obtained from two walks was recorded and they were given a score according to their time. These are the scores that were assigned: $0=$ could not perform the test; 1 = longer than $6.52 \mathrm{sec}$; $2=$ between 4.66 and $6.52 \mathrm{sec}$.; $3=$ between 3.62 and $4.65 \mathrm{sec}$.; 4 = less than $3.62 \mathrm{sec}$.

Lower limb strength was evaluated using the chair stand test. The elderly subjects kept their arms crossed over their chests, and at the evaluator's signal stood up and sat down in a chair five times as quickly as they could without a pause. Those who could not perform the task described in less than 60 seconds were classified as unable to perform the test. The scores on this test were: $0=$ unable to perform the test; 1 = time above or equal to $16.70 \mathrm{sec}$; $2=$ time between 13.70 and $16.69 \mathrm{sec}$.; $3=$ time between 11.20 and $13.69 \mathrm{sec}$; 4 = time below or equal to $11.19 \mathrm{sec}$.

Mobility was classified in the individual tests as: low for those seniors who scored $0-2$ points and high for those with 3 - 4 points. When considering the combined scores from all three tests ( 0 - 12 points), the elderly who scored 0 - 6 points were considered to have low mobility and those with $7-12$ points high mobility. 


\section{Statistical Analysis}

The chi-square test (crosstabs) was used to analyze the relationship between sociodemographic factors, NCDs and mobility. Binary logistic regression analysis was used to express the magnitude of the relationships in Odds Ratio (OR) values with $95 \%$ confidence intervals. All variables with $\mathrm{p}<0.20$ were selected and included in the construction of a binary multiple logistic regression model using the forward stepwise modeling strategy. Statistical analysis was conducted using SPSS software (SPSS inc. Chicago, IL), version 17.0. The level of significance was set at $5 \%$.

\section{Results}

The majority of the oldest old investigated in this study were Caucasian women who were between 80 and 84 years of age, had low education levels and were widowed. Regarding their nutritional status and the presence of chronic diseases, most were of normal weight and had high blood pressure and osteoarticular diseases. Elderly people aged 85 years or older with a low education level demonstrated less mobility when compared with those between 80 to 84 years old $(p=0.034)$ and a high education level $(p=0.000)$ (Table 1).

Table 1 - Relationship between sociodemographic factors, NCDs and mobility of the oldest old

\begin{tabular}{|c|c|c|c|c|c|c|}
\hline \multirow{2}{*}{ Variables } & & & \multirow{2}{*}{ Total (n) } & \multicolumn{2}{|c|}{ Mobility } & \multirow{2}{*}{$\mathrm{p}$} \\
\hline & & & & Low & High & \\
\hline \multirow[t]{2}{*}{ Gender } & \multicolumn{2}{|l|}{ Male } & 44 & $52.3 \%$ & $47.7 \%$ & \multirow{2}{*}{0.205} \\
\hline & Female & & 76 & $65.8 \%$ & $34.2 \%$ & \\
\hline \multirow[t]{2}{*}{ Age } & $80-84$ & & 94 & $55.3 \%$ & $44.7 \%$ & \multirow{2}{*}{0.034} \\
\hline & \multicolumn{2}{|l|}{$>85$} & 26 & $80.8 \%$ & $19.2 \%$ & \\
\hline Nutritional & \multicolumn{2}{|l|}{ Underweight } & 33 & $72.7 \%$ & $27.3 \%$ & \multirow{3}{*}{0.150} \\
\hline \multirow[t]{2}{*}{ Status } & \multicolumn{2}{|l|}{ Normal } & 50 & $56 \%$ & $44 \%$ & \\
\hline & \multicolumn{2}{|l|}{ Obese } & 37 & $56.8 \%$ & $43.2 \%$ & \\
\hline \multirow[t]{3}{*}{ Education } & \multicolumn{2}{|l|}{ None } & 36 & $75 \%$ & $25 \%$ & \multirow{3}{*}{$\leq 0.001$} \\
\hline & \multicolumn{2}{|l|}{ Primary } & 70 & $62.9 \%$ & $37.1 \%$ & \\
\hline & \multicolumn{2}{|c|}{ Secondary/Higher } & 14 & $14.3 \%$ & $85.7 \%$ & \\
\hline \multirow[t]{3}{*}{ Marital Status } & \multicolumn{2}{|c|}{ Single/Separated } & 09 & $44.4 \%$ & $55.6 \%$ & \multirow{3}{*}{0.064} \\
\hline & \multicolumn{2}{|c|}{ Married/Cohabiting } & 46 & $52.2 \%$ & $47.8 \%$ & \\
\hline & \multicolumn{2}{|l|}{ Widowed } & 65 & $69.2 \%$ & $30.8 \%$ & \\
\hline \multirow[t]{4}{*}{ Ethnicity } & \multicolumn{2}{|l|}{ White } & 70 & $58.6 \%$ & $41.4 \%$ & \multirow{4}{*}{0.350} \\
\hline & \multicolumn{2}{|l|}{ Black } & 06 & $33.3 \%$ & $66.7 \%$ & \\
\hline & \multicolumn{2}{|l|}{ Yellow } & 17 & $70.6 \%$ & $29.4 \%$ & \\
\hline & \multicolumn{2}{|l|}{ Brown } & 27 & $66.7 \%$ & $33.3 \%$ & \\
\hline \multirow[t]{6}{*}{ Diseases } & Hypertension & yes & 77 & $58.7 \%$ & $41.3 \%$ & 060 \\
\hline & & no & 43 & $64.3 \%$ & $35.7 \%$ & \\
\hline & Diabetes & yes & 23 & $63.6 \%$ & $36.4 \%$ & 0 \\
\hline & & no & 97 & $60 \%$ & $40 \%$ & 0.942 \\
\hline & Osteoarticular & yes & 62 & $56.7 \%$ & $43.3 \%$ & 0160 \\
\hline & & no & 58 & $64.9 \%$ & $35.1 \%$ & 0.405 \\
\hline
\end{tabular}


Table 2 shows the odds ratio value obtained through binary logistic regression analysis, together with their respective 95\% confidence intervals. Only age and education appear to be associated with mobility, with seniors aged 85 years or older and no education at higher risk for limited mobility $(p<0.05)$.

Table 2 - Odds ratio for limited mobility according to sociodemographic factors and NCDs

\begin{tabular}{|c|c|c|c|}
\hline Variables & OR & Cl (95\%) & $\mathbf{P}$ \\
\hline \multicolumn{4}{|l|}{ Gender } \\
\hline Male & 1.00 & ----- & \\
\hline Female & 1.76 & $0.82-3.75$ & 0.145 \\
\hline \multicolumn{4}{|l|}{ Age } \\
\hline 80-84 years & 1.00 & ------ & \\
\hline$>85$ years & 3.39 & $1.18-9.76$ & 0.023 \\
\hline \multicolumn{4}{|l|}{ Education level } \\
\hline Educated & 1.00 & ----- & \\
\hline Uneducated & 2.48 & $1.04-5.90$ & 0.040 \\
\hline \multicolumn{4}{|l|}{ Marital Status } \\
\hline $\begin{array}{l}\text { Married/ } \\
\text { Cohabiting }\end{array}$ & 1.00 & ----- & \\
\hline $\begin{array}{l}\text { Single/ } \\
\text { Separated/ } \\
\text { Widowed }\end{array}$ & 1.59 & $0.75-3.36$ & 0.223 \\
\hline \multicolumn{4}{|l|}{ Ethnicity } \\
\hline White & 1.00 & ----- & \\
\hline Black/Brown & 1.17 & $0.50-2.71$ & 0.713 \\
\hline Asian & 1.74 & $0.55-5.48$ & 0.344 \\
\hline \multicolumn{4}{|l|}{$\begin{array}{l}\text { Nutritional } \\
\text { Status }\end{array}$} \\
\hline Normal & 1.00 & ----- & \\
\hline Underweight & 2.09 & $0.81-5.41$ & 0.126 \\
\hline Obese & 1.03 & $0.44-2.43$ & 0.944 \\
\hline \multicolumn{4}{|l|}{ Hypertension } \\
\hline Normotensive & 1.00 & ----- & \multirow[b]{2}{*}{0.551} \\
\hline Hypertensive & 0.79 & $0.36-1.72$ & \\
\hline \multicolumn{4}{|l|}{ Diabetes } \\
\hline Normal & 1.00 & ---- & \multirow[b]{2}{*}{0.753} \\
\hline Diabetic & 1.17 & $0.45-3.05$ & \\
\hline \multicolumn{4}{|l|}{$\begin{array}{l}\text { Osteoarticular } \\
\text { Diseases }\end{array}$} \\
\hline Normal & 1.00 & ----- & \\
\hline Present & 0.71 & $0.33-1.49$ & 0.362 \\
\hline
\end{tabular}

Note: $\mathrm{Cl}=$ confidence interval; $\mathrm{OR}=$ odds ratio.
Table 3 shows the multiple regression model containing sociodemographic factors related to limited mobility. Age is related to limited mobility independent of other variables, such as education, marital and nutritional statuses, and gender.

Table 3 - Multiple logistic regression model with sociodemographic factors related to mobility limitation in the oldest old

\begin{tabular}{lccc}
\hline Variables & AOR & Cl (95\%) & P \\
\hline $\begin{array}{l}\text { Education } \\
\text { Educated }\end{array}$ & 1.00 & ----- & \\
Uneducated & 2.27 & $0.91-5.66$ & 0.078 \\
Age & & & \\
80 - 84 years & 1.00 & ----- & \\
$>85$ years & 3.29 & $1.09-9.87$ & 0.034 \\
\hline Marital Status & & & \\
Married/Cohabiting & 1.00 & ----- & \\
Single/Separated/ & 0.75 & $0.31-1.86$ & 0.537 \\
Widowed & & & \\
Nutritional Status & & & \\
Normal & 1.00 & ----- & \\
Underweight & 1.14 & $0.46-2.84$ & 0.772 \\
Obese & 1.77 & $0.64-4.85$ & 0.268 \\
Gender & & & \\
Male & 1.00 & ----- & 0.279 \\
Female & 1.64 & $0.67-4.04$ & \\
\hline
\end{tabular}

Note: $\mathrm{Cl}=$ confidence interval; $\mathrm{AOR}=$ adjusted odds ratio; HosmerLemeshow test $=0,71$.

\section{Discussion}

In this study, we decided to analyze which sociodemographic factors and NCDs affect the mobility of the oldest old. Balance, walking speed and lower limb strength of these seniors were evaluated by a battery of tests. It was observed that education and age are associated with decreased mobility in this age group.

There is an inverse relationship between age and mobility. This relationship was also observed in São Paulo $(15,8)$ and all regions of Brazil. In the aforementioned studies which considered the young elderly, age stratification was done in decades. In this study of the oldest old, age stratification was done in five year periods. Thus, our 
results indicate that there is a relationship between age and mobility. Elderly people who are 85 years old or older have less mobility when compared to those between 80 and 84 years old. The oldest old are three times more likely to have limited mobility than the younger elderly. This relationship remained constant when the multiple regression model was built and it was observed that age is related to limited mobility independent of other variables, such as education, marital and nutritional statuses, and gender.

This result is alarming considering that reduced mobility is a risk factor for functional dependence and the elderly who are over 85 years old are three times more likely to be functionally dependent than those who are younger than 85 (16). One of the most plausible explanations for this phenomenon is the higher incidence of sarcopenia in this segment of the population as it ages (17). Sarcopenia results in the loss of muscle mass and strength and consequently the reduction in mobility as the elderly age.

In reference to education, it was determined that there is a relationship between reduced mobility and a low level of education among both genders of the oldest old. Elderly people with little or no education were approximately two times more likely to have limited mobility than those with a higher level of education. There are other reports about mobility and education in individuals over the age of 55 (7). The authors of these reports also found that those with a poor education had less mobility when compared to those with a higher level of education. Gregory et al. (9) reached the same conclusion when studying the association between limited mobility and a low level of education in seniors aged between 70 and 79 . This relationship can be attributed to a decreased capacity for understanding preventive measures, less investment in health and disability prevention $(18,19)$, as well as the possibility of poorly educated elderly people coming from precarious home and family environments (20). It is also worth noting that the understanding the elderly have regarding the importance of physical activity may also factor in due to the close association between physical activity and functional capacity (21).

With regard to the differences between genders and mobility, this study showed that the number of men with limited mobility was similar to the number with high mobility and that among females there are approximately twice as many of the oldest old women with low mobility when compared to women with high mobility. However, this study did not identify any statistical significance between gender and mobility $(p=0.205)$. There are other studies, though, which point out differences between the genders in relation to mobility, with females being at a greater risk of decreased mobility $(8,15)$. One explanation for this may be the higher incidence of vascular and osteoarticular diseases, as well as obesity in women (22). In the study by Barbosa et al. (15), it was observed that men in all age groups demonstrated greater mobility than women, which is similar to recent results (11).

Nutritional status may also be used to indicate mobility, since a low weight (23) and obesity (24) can be associated with decreased mobility. One study (23) established that elderly patients who lost $10 \%$ of their weight over a 2 year period were at a $2.2 \%$ greater risk of decreased mobility. Excess body fat can also limit mobility. The higher proportion of body fat accentuates the risk of disability in overweight older people by increasing body burden, limiting movements and increasing stress on joints and muscles (3). Other authors (25) have also observed that excess body fat limits mobility among the elderly. There are other studies (26) which have shown that the relationship between body fat and mobility is more significant for seniors who are between 60 and 79 years old. These same studies indicate that this association is not as clear among the older elderly. These findings contradict the results of this study which establishes a clear association between nutritional status and mobility among the oldest old.

Marital status, ethnicity and the presence of NCDs are other variables which we studied that did not show statistical significance. Even though there are a greater number of widowed seniors with reduced mobility, marital status has no statistical significance. In general, different studies have found that people living alone (single, divorced or widowed), especially elderly men, have a higher risk of functional limitations (27) and decreased mobility (28).

In a similar way, this study indicates that ethnicity is not associated with mobility, but there was another study done (10) which shows that this variable can indeed be associated with mobility among seniors. This study observed that elderly black people between 70 and 79 years old were less mobile than their white counterparts. However, this may not be the result of ethnicity itself but rather complicating factors, such as lower socioeconomic status and education and poorer health of the majority of individuals within this ethnic group (29). 
Finally, the contribution of NCDs to functional disability is higher among the oldest old (2). Recent studies (4) found that the relationship between disability and NCDs in the elderly has hardly changed in the last decade. This same study affirms that diabetes has a greater influence on disability than hypertension. Winter et al. (30) observed that individuals with osteoarticular diseases have less mobility than their healthy peers. In this study none of the investigated diseases (hypertension, diabetes and osteoarticular diseases) were associated with the mobility of the oldest old. This result may be related to the fact that despite the high prevalence of these diseases among the oldest old, early detection and improvements in treatment may be preventing them from affecting their mobility. In addition to this, other factors that are closely related to mobility, such as age, can independently cause reduced mobility in this age group.

It is important to remember that the cross-sectional design of this study does not allow for the establishment of a causal relationship. Other factors which may be related to decreased mobility, such as the physical and professional activities engaged in during the majority of their economically active life, were not investigated. However, it is worth emphasizing that there are only a limited number of studies which seek to analyze these aspects in the elderly who are over the age of eighty.

\section{Conclusion}

This study concludes that the oldest old aged 85 or older are at a greater risk of reduced mobility, independent of their education level, marital and nutritional statuses and gender. We encourage others to study not only aspects addressed in this study, but to also examine aspects related to family life, especially using longitudinal studies.

\section{References}

1. Instituto Brasileiro de Geografia e Estatística/IBGE. Censo Demográfico e Contagem da População: População residente por gênero, situação e grupos de idade. 2010 [cited 2012 Sep 10]. Available from: http//www. sidra.ibge.gov.br.
2. Klijs B, Nusselder WJ, Looman CW, Mackenbach JP. Contribution of chronic disease to the burden of disability. PloS One. 2011;6(9):e25325.

3. Bouchard DR, Choquette S, Dionne IJ, Brochu M. Is fat mass distribution related to impaired mobility in older men and women? Nutrition as a determinant of successful aging: the Quebec longitudinal study. Exp Aging Res. 2011;37(3):346-57.

4. Hung WW, Ross JS, Boockvar KS, Siu AL. Association of chronic diseases and impairments with disability in older adults: a decade of change? Med Care. 2012;50(6):501-7.

5. Satariano WA, Guralnik JM, Jackson RJ, Marottoli RA, Phelan EA, Prohaska TR. Mobility and aging: new directions for public health action. Am J Public Health. 2012;102(8):1508-15.

6. Guralnik JM, Simonsick EM, Ferrucci L, Glynn RJ, Berkman LF, Blazer DG, et al. A short physical performance battery assessing lower extremity function: association with self-reported disability and prediction of mortality and nursing home admission. J Gerontol. 1994;49(2):M85-94.

7. Sainio P, Martelin T, Koskinen S, Heliovaara M. Educational differences in mobility: the contribution of physical workload, obesity, smoking and chronic conditions. J Epidemiol Community Health. 2007;61(5):401-8.

8. Parahyba MI, Veras R. Diferenciais sociodemográficos no declínio funcional em mobilidade física entre os idosos no Brasil. Cien Saude Coletiva. 2008;13(4):1257-64.

9. Gregory PC, Szanton SL, Xue QL, Tian J, Thorpe RJ, Fried LP. Education predicts incidence of preclinical mobility disability in initially high-functioning older women. The Women's Health and Aging Study II. J Gerontol A Biol Sci Med Sci. 2011;66(5):577-81.

10. Thorpe Jr RJ, Koster A, Kritchevsky SB, Newman AB, Harris T, Ayonayon HN, et al. Race, socioeconomic resources, and late-life mobility and decline: findings from the Health, Aging, and Body Composition study. J Gerontol A Biol Sci Med Sci. 2011;66(10):1114-23.

11. Miszkurka M, Zunzuneguia MV, Langloisa EV, Freemanb $\mathrm{EE}$, Kouandac S, Haddada S. Gender differences in mobility disability during young, middle and older age in West African adults. Glob Public Health. 2012;7(5):495-508. 
12. Troiano RP, Frongillo EAJR, Sobal J, Levitsky DA. The relationship between body weight and mortality: a quantitative analysis of combined information from existing studies. Int J Obes Relat Metab Disord. 1996;20(1):63-75.

13. Washington State Health Insurance Pool. Standard Health Questionnaire for Washington State. Washington; 2005.

14. Freitas Jr IF, Castoldi RC, Moreti DG, Pereira ML, Cardoso ML, Codogno JS, et al. Aptidão física, historia familiar e ocorrência de hipertensão arterial, osteoporose, doenças metabólicas e cardíacas entre mulheres. Rev SOCERJ. 2009;22(3):158-64.

15. Barbosa AR, Souza JMP, Lebrão ML, Laurenti R, Marucci MFN. Functional limitations of Brazilian elderly by age and gender differences: data from SABE Survey. Cad Saude Publica. 2005;21(4):1177-85.

16. Nogueira SL, Ribeiro RCL, Rosado LEFPL, Franceschini SCC, Ribeiro AQ Pereira ET. Fatores determinantes da capacidade funcional em idosos longevos. Rev Bras Fisioter. 2010;14(4):322-9.

17. Baumgartner RN, Koehler KM, Gallagher D, Romero L, Heymsfield SB, Ross RR, et al. Epidemiology of sarcopenia among the elderly in New Mexico. Am J Epidemiol. 1998;147(8):755-63.

18. Sudore RL, Yaffe K, Satterfield S, Harris TB, Mehta KM, Simonsick EM, et al. Limited literacy and mortality in the elderly: the health, aging, and body composition study. J Gen Intern Med. 2006;21(8):806-12.

19. Baker DW, Wolf MS, Feinglass J, Thompson BA, Gazmararian JA, Huang J. Health literacy and mortality among elderly persons. Arch Intern Med. 2007;167(14):1503-9.

20. Petersen KL, Marsland AL, Flory J, Vortruba-Drzal E, Muldoon MF, Manuck SB. Community socioeconomic status is associated with circulating interleukin- 6 and C-reactive protein. Psychosom Med. 2008;70(6):646-52.

21. Cipriani NCS, Meurer ST, Benedetti TRB, Lopes MA. Aptidão funcional de idosas praticantes de atividades físicas. Rev. bras. cineantropom. desempenho Hum. 2010;12(2):106-11.

22. Whitson HE, Landerman LR, Newman AB, Fried LP, Pieper CF, Cohen HJ. Chronic medical conditions and the gender-based disparity in disability: the cardiovascular health study. J Gerontol A Biol Sci Med Sci. 2010;65(12):1325-31.
23. Bannermann E, Miller MD, Daniels LA, Cobiac L, Giles LC, Whitehead C, et al. Anthropometric indices predict physical function and mobility in older Australians: the Australian Longitudinal Study of Ageing. Public Health Nutr. 2002;5(5):655-62.

24. Stenholm S, Rantanen T, Alanen E, Reunanen A, Sainio P, Koskinen S. Obesity history as a predictor of walking limitation at old age. Obesity. 2007;15(4):929-38.

25. Barbosa AR, Souza JMP, Lebrão ML, Marucci MFN. Estado nutricional e desempenho motor de idosos de São Paulo. Rev Assoc Med Bras. 2007;53(1):75-9.

26. Sallinen J, Stenholm S, Rantanen T, Helioaara M, Sainio $\mathrm{P}$, Koskinen S. Effect of age on the association between body fat percentage and maximal walking speed. J Nutr Health Aging. 2011;15(6):427-32.

27. Altmets K, Puur A, Uusküla A, Saava A, Sakkeus L, Katus K. Self-reported activity limitations among the population aged 20-79 in Estonia: a cross-sectional study. Eur J Public Health. 2011;21(1):49-55.

28. Nilsson CJ, Avlund K, Lund R. Onset of mobility limitations in old age: the combined effect of socioeconomic position and social relations. Age Ageing. 2011;40(5):607-14.

29. Williams DR, Sternthal M. Understanding racial-ethnic disparities in health: sociological contributions. J Health Soc Behav. 2010;51 Suppl:S15-27.

30. Winter CC, Brandes M, Muller C, Schubert T, Ringling $\mathrm{M}$, Hillmann A, et al. Walking ability during daily life in patients with osteoarthritis of the knee or the hip and lumbar spinal stenosis: a cross sectional study. BMC Musculoskelet Disord. 2010;11:233.

Received in 10/14/2013 Recebido em 14/10/2013

Approved in 03/08/2016 Aprovado em 08/03/2016 